\title{
Nutritional Evaluation of Selected Traditional Foods Commonly Consumed in Saudi Arabia
}

\author{
Nora Abdullah Al-Faris* \\ Nutrition and Food Science Department, College of Home Economics, Princess Nourah Bint Abdulrahman University, \\ PO Box 27938, Riyadh, 11427, Saudi Arabia \\ *Corresponding author: naalfaris@pnu.edu.sa
}

\begin{abstract}
During the last few decades, Saudi Arabia experienced rapid nutritional transition associated with an alarming elevation in the prevalence of obesity and related chronic diseases. Traditional foods contribute to the usual diet of the population in Saudi Arabia and the nutritional evaluation of traditional foods is necessary to accurately estimate dietary intakes of the Saudi population. Therefore, the objective of the current work is to evaluate twentyfive traditional foods commonly consumed in Saudi Arabia based on their nutritional composition. Proximate composition and vitamin $\mathrm{D}$, calcium, phosphorus, iron, phytate and oxalate content were investigated. On fresh weight basis, the analyzed foods contained $1.17-16.19 \%(\mathrm{~N} \times 6.25)$ protein, $0.25-17.84 \%$ fat, $2.57-68.30 \%$ carbohydrate, $0.31-2.26 \%$ dietary fiber, $0.67-2.90 \%$ ash and $17-430 \mathrm{kcal} / \mathrm{g}$. The vitamin D content ranged from 0.0$75.88 \mathrm{IU} / 100 \mathrm{~g}$. Mineral content (mg/100g) of calcium, phosphorus and iron were 13.62-91.37, 22.33-200.37 and 0.51-4.44 respectively. Phytate and oxalate content (mg/100g) were 2.25-148.52 and 1.02-48.63 respectively. The studied traditional foods contributed $15-91 \%, 3-69 \%$ and $2-30 \%$ of the total food energy from carbohydrate, fat and protein respectively. Data from this study will be important to clarify nutritional value and nutrient contribution from common traditional foods in Saudi Arabia. Saudi dietary guidelines should take into consideration, the nutritive value and health aspects of traditional foods.
\end{abstract}

Keywords: Saudi Arabia, proximate composition, vitamin D, minerals, phytate, oxalate

Cite This Article: Nora Abdullah Al-Faris, "Nutritional Evaluation of Selected Traditional Foods Commonly Consumed in Saudi Arabia." Journal of Food and Nutrition Research, vol. 5, no. 3 (2017): 168-175. doi: 10.12691/jfnr-5-3-5.

\section{Introduction}

The Kingdom of Saudi Arabia has experienced fast and complete epidemiologic and nutritional transition over the last four decades [1]. Rapid economic growth fuelled by oil revenues led to a remarkable change in the lifestyle of Saudis toward westernised lifestyle which is characterised by unhealthy dietary patterns and sedentary behaviours $[2,3]$. These changes are associated with a dramatic increase in the prevalence of obesity and related chronic diseases, such as type 2 diabetes and cardiovascular disease, in Saudi Arabia [4,5,6]. A national based survey conducted by the Saudi Ministry of Health in collaboration with the Institute for Health Metrics and Evaluation in 2013 found that $28.7 \%$ of Saudis aged 15 years or older were obese [4]. Further, International Diabetes Federation reported that 3.4 million Saudis suffering from diabetes in 2015 constituted 17.6\% of adults aged 20-79 years [5]. In the same fashion, coronary heart disease constitutes the third most common cause of hospital-based mortality after accidents and senility in Saudi Arabia [6].

Traditional foods are those proven to be consumed regionally by a specific community, for a period of time showing transmission between generations [7]. Traditional foods; either homemade foods or out-of-home foods purchased from local food outlets, still contribute to people's usual diet. Therefore, the nutritional evaluation of traditional foods is necessary to estimate population dietary intakes accurately [7]. Unfortunately, information about nutritional composition data of traditional foods is missing for most current national food composition databases [8]. Nutritional evaluations of some traditional foods have been investigated in Saudi Arabia $[9,10,11]$ and other neighbouring Arab Gulf countries [12,13,14]. However, many traditional foods commonly consumed in Saudi Arabia were not evaluated in these studies. In addition, possible variations resulting from differences in the ingredients and methods of preparation across Saudi Arabia and neighbouring countries in the gulf region may exist [12]. Therefore, it is important to determine the nutritive values of traditional Saudi foods through generating their nutritional composition data.

The aim of this study is to evaluate the nutritional value of twenty-five traditional foods commonly consumed in Saudi Arabia based on their proximate composition and content of vitamin D, calcium, phosphorus, iron, phytate and oxalate. 


\section{Materials and Methods}

\subsection{Traditional Foods Selection and Preparation}

For the current study, twenty-five traditional foods commonly consumed in Saudi Arabia were selected. The selection was based on data obtained from a pilot survey of one hundred Saudi housewives living in Riyadh; the capital city of Saudi Arabia. Prior to taking part in the pilot survey, all participants signed a consent form in accordance with the declaration of Helsinki. The mostcommonly consumed twenty-five traditional foods were determined. In addition, the common way of getting these foods was collected. Consequently, the selected foods were categorised to homemade foods $(n=15)$ and out-ofhome foods $(n=10)$ which are purchased from local food outlets. Information on the main ingredients and the cooking procedures for the homemade foods were collected during the pilot survey. Two batches of the average recipe for each food item were prepared by two different Saudi housewives by using the traditional cooking methods. Moreover, the main local food outlets in Riyadh city were targeted to obtain two samples of the out-of-home foods. The two samples of each food item were pooled into a single and homogenous sample. All samples were rapidly transferred to the sample containers and stored in freezers for later chemical analysis. The study was approved by the Nutrition and Food Science Department, College of Home Economics, Princess Nourah Bint Abdulrahman University, Riyadh, Saudi Arabia. Local names of traditional Saudi foods and their main ingredients are presented in Table 1.

\subsection{Chemical Analysis}

Proximate composition analysis was conducted to measure the moisture, protein $(\mathrm{N} \times 6.25)$, fat, ash, crude fibre and carbohydrate (by difference) in duplicate, according to the Association of Official Analytical Chemists (AOAC) standard procedures [15]. The vitamin D content was determined by the Roche Diagnostics Vitamin D total assay as described by Haq [16]. For the analysis of minerals ( $\mathrm{Ca}, \mathrm{P}$ and $\mathrm{Fe}$ ), the microwave digestion technique was used to process the samples and the flame atomic absorption spectrophotometer was used to determine mineral concentrations according to the method of AOAC [15]. Phytate content was determined according to the method described by Mameesh and Tomar [17]. Finally, oxalate content was determined according to the method of AOAC [15].

Table 1. Local Names, and Main Ingredients of Selected Traditional Foods Commonly Consumed in Saudi Arabia

\begin{tabular}{|c|c|c|}
\hline No. & Local Name* & Main ingredients \\
\hline 1 & Gerish & Whole wheat groats, laban (sour milk), butter, onion, butter, cumin, salt. \\
\hline 2 & Qorsan & $\begin{array}{l}\text { Whole wheat flour, lamb meat, butter, zucchini, eggplants, pumpkin, green beans, dried black lime, tomatoes, } \\
\text { carrots, onion, tomato paste, black pepper, dried coriander, cinnamon, garlic, curcuma, salt. }\end{array}$ \\
\hline 3 & Marqooq & $\begin{array}{l}\text { Whole Wheat flour, meat, onion, garlic, dried lime, tomato paste, tomatoes, zucchini, eggplants, pumpkin, carrots, } \\
\text { spices, pepper, butter, hot pepper, salt. }\end{array}$ \\
\hline 4 & Marassia & Whole wheat flour, butter, eggs, milk, tomato, onion, curcuma, salt. \\
\hline 6 & Mulukhiyah & Jew’s mallow leaves, meat, tomatoes, onion, garlic, coriander, salt. \\
\hline 7 & Kabsah lahem & Meat, onion, garlic, vegetable oil, rice, tomatoes, spices, tomato paste, salt. \\
\hline 8 & Moussakat bathenjan & Eggplant, potatoes, tomatoes, green pepper, ground meat, vegetable oil, garlic, curcuma, pine, tomato paste, salt. \\
\hline 9 & Maraq bamieh & Okra, tomato sauce, meat, salt. \\
\hline 10 & Makaronah bebashamel & Ground meat, onion, garlic, tomato sauce, pepper, milk, butter, flour, pasta, salt. \\
\hline 12 & Batata mihshi & Potatoes, tomatoes, vegetable oil, ground meat, parsley, onion, pepper, cinnamon, cumin, salt. \\
\hline 13 & Henany & Dates, whole wheat flour, butter, black pepper. \\
\hline 14 & Mohala & Dates, whole wheat flour, butter, black pepper. \\
\hline 15 & Aseedeh & Millet flour, butter, salt. \\
\hline 16 & Fatayer sabanek & Spinach leaves, onions, lemon juice, black pepper, sumac, vegetable oil, salt. \\
\hline 17 & Falafel & Chickpeas, onion, garlic, pepper, parsley, salt. \\
\hline 18 & Foul mudames & Fava beans, tahini, vegetable oil, lemon juice, garlic, salt. \\
\hline 19 & Hummus & Chickpeas, tahini, vegetable oil, lemon juice, garlic, salt. \\
\hline 20 & Mafroud burr bread & Whole wheat bread, eggs, milk, vegetable oil, yeast, sugar, salt. \\
\hline 21 & Samouli burr bread & Whole wheat flour, milk, vegetable oil, sugar, yeast, salt. \\
\hline 24 & Mutabak & Whole wheat flour, vegetable oil, eggs, onion, garlic, ground meat, tomatoes, spices, green onion, salt. \\
\hline 25 & Mamoul tamer & White wheat flour, butter, yeast, spices, mashed dates, salt. \\
\hline
\end{tabular}

*Food items 1-15 are homemade foods and food items 16-25 are out-of-home foods. 


\subsection{Data Analysis}

The food energy content per $100 \mathrm{~g}$ serving size of the analysed foods was estimated by the sum of the carbohydrate, fat and protein percentages after multiplying them by the Atwater factors (4, 9 and 4, respectively). In addition, the food energy contribution from macronutrients and the nutrient adequacy ratios (\%) for $100 \mathrm{~g}$ serving size of selected foods for middle age adults (31-50 year) were calculated. The Statistical Package for Social Sciences (SPSS Inc., Chicago, IL, USA) version 20 was used for data analysis.

\section{Results and Discussion}

Data on the proximate composition of twenty-five traditional foods commonly consumed in Saudi Arabia are given in Table 2 . There were considerable variations in the nutritional composition of the selected foods. Results revealed that eighteen food items had a moisture level higher than 50\%. The lowest and highest moisture content were shown in Kulaija (12.82\%) and Mulukhiyah (95.07\%). Protein content ranged from $1.17 \%$ reported in Mulukhiyah to $16.19 \%$ reported in Henany. The lowest fat content was found in both Mulukhiyah and Maraq bamieh $(0.25 \%)$, while the highest fat content was found in Hummus (17.84\%). Ash and fibre content did not vary much between the studied food items. The least ash content was reported in Mohala (0.67\%) and the highest ash content was reported in Falafel (2.90\%). Aseedeh was found with the lowest fibre content $(0.31 \%)$, while Moussakat bathenjan was found with the highest fibre content (2.26\%). Five of the analysed foods had carbohydrate content higher than 50\%. Carbohydrate content ranged from $2.57 \%$ reported in Mulukhiyah to 68.30\% reported in Mafroud burr bread. Several studies were carried out previously by Al-Kanhal and colleagues $[9,10,11]$ to investigate the nutritional composition of several traditional foods commonly consumed in Saudi Arabia. Al-Kanhal et al. [9] studied the nutritive value of some wheat-based Saudi traditional foods, including; Gerish, Qorsan, Marqooq, Marassia and Harees. In subsequent reports, some legume-based foods (including; Foul mudames, Falafel and Hummus), and rice-based foods (including; Kabsah) commonly consumed in Saudi Arabia were analyed for proximate composition [10,11]. Compared to our findings, they reported a lower content of protein (except for Qorsan, Falafel and Hummus) and carbohydrate (except for Harees and Kabsah) and a higher content of dietary fibre and fat (except for Harees, Hummus and Kabsah). Generally, variations observed in proximate composition between current and previous data could be caused by variations in the used ingredients or preparation methods.

Table 2. Proximate Composition of Selected Traditional Foods Commonly Consumed in Saudi Arabia.

\begin{tabular}{|c|c|c|c|c|c|c|c|}
\hline No. & Food Items & Water & Protein & Fat & Ash & Fiber & Carbohydrate \\
\hline 1 & Gerish & 80.19 & 3.61 & 0.47 & 1.37 & 0.38 & 14.36 \\
\hline 2 & Qorsan & 79.38 & 3.98 & 1.16 & 1.33 & 0.83 & 14.15 \\
\hline 3 & Marqooq & 76.99 & 4.57 & 0.48 & 1.04 & 1.11 & 16.92 \\
\hline 4 & Marassia & 53.33 & 8.81 & 3.04 & 1.12 & 1.23 & 33.70 \\
\hline 5 & Harees & 80.64 & 2.98 & 4.06 & 0.96 & 0.65 & 11.36 \\
\hline 6 & Mulukhiyah & 95.07 & 1.17 & 0.25 & 0.94 & 0.52 & 2.57 \\
\hline 7 & Kabsah lahem & 67.14 & 5.54 & 1.88 & 0.98 & 0.44 & 24.46 \\
\hline 8 & Moussakat bathenjan & 65.36 & 8.86 & 16.38 & 1.46 & 2.26 & 7.94 \\
\hline 9 & Maraq bamieh & 92.36 & 2.10 & 0.25 & 0.97 & 0.49 & 4.32 \\
\hline 10 & Makaronah bebashamel & 71.74 & 5.69 & 5.09 & 1.11 & 0.55 & 16.37 \\
\hline 11 & Kushary & 64.94 & 2.17 & 4.48 & 1.24 & 0.51 & 27.17 \\
\hline 12 & Batata mihshi & 72.81 & 8.48 & 5.94 & 1.47 & 0.84 & 11.30 \\
\hline 13 & Henany & 23.53 & 16.19 & 4.91 & 1.40 & 2.01 & 53.97 \\
\hline 14 & Mohala & 65.36 & 2.96 & 2.48 & 0.67 & 1.08 & 28.53 \\
\hline 15 & Aseedeh & 71.04 & 3.61 & 2.63 & 0.88 & 0.31 & 21.84 \\
\hline 16 & Fatayer sabanek & 49.19 & 5.39 & 2.84 & 2.06 & 1.17 & 40.52 \\
\hline 17 & Falafel & 45.32 & 9.00 & 14.29 & 2.90 & 2.25 & 28.49 \\
\hline 18 & Foul mudames & 70.37 & 7.96 & 3.20 & 1.32 & 0.50 & 17.15 \\
\hline 19 & Hummus & 55.94 & 8.44 & 17.84 & 1.92 & 1.36 & 15.86 \\
\hline 20 & Mafroud burr bread & 25.35 & 4.10 & 1.09 & 1.16 & 0.95 & 68.30 \\
\hline 21 & Samouli burr bread & 28.58 & 1.35 & 2.69 & 1.18 & 1.00 & 66.20 \\
\hline 22 & Warak inab mihshi & 72.31 & 2.76 & 3.75 & 1.86 & 0.98 & 19.32 \\
\hline 23 & Kulaija & 12.82 & 6.83 & 17.47 & 1.58 & 1.01 & 61.30 \\
\hline 24 & Mutabak & 60.83 & 8.44 & 5.46 & 1.68 & 0.52 & 23.59 \\
\hline 25 & Mamoul tamer & 18.48 & 4.60 & 10.23 & 1.49 & 1.35 & 65.20 \\
\hline
\end{tabular}


The dietary energy content per $100 \mathrm{~g}$ of the analysed foods ranged from $17 \mathrm{kcal}$ (73 kJ) reported in Mulukhiyah to $430 \mathrm{kcal}(1805 \mathrm{~kJ})$ reported in Kulaija (Table 3). The dietary energy contribution varies among the different food items. The selected traditional foods contributed $15-91 \%$, 3-69\% and $2-30 \%$ of the total food energy from carbohydrate, fat and protein respectively. In fact, carbohydrate contributes to more than half of the energy content of nineteen food items. Contrarily, fat contributes to more than half of the energy content of only two food items. Moussakat bathenjan provides only $15 \%$ of its energy content as a carbohydrate, while it provides most of its energy content as a fat (69\%). In contrast, Mafroud burr bread derives most of its energy content from carbohydrate (91\%) and a few calories from fat (3\% of its energy content). Samouli burr bread and Maraq bamieh were found with the lowest (2\%) and highest (30\%) energy contribution of protein respectively. The Food and Nutrition Board of the Institutes of Medicine, National Academies, United States developed Acceptable Macronutrient Distribution Ranges (AMDRs) for macronutrients. The AMDRs for carbohydrate (45\%-65\% of food energy), protein (10\%-35\% of food energy), and fat (20\%-35\% of food energy) provide a range broad enough to cover the macronutrients needs of most individuals [18]. Actually, most of the selected traditional foods are good sources of carbohydrate and protein. While only four food items (Moussakat bathenjan, Hummus,
Batata mihshi and Falafel) contribute less than $45 \%$ of food energy as a carbohydrate, seven food items (Kushary, Mohala, Mafroud burr bread, Samouli burr bread, Warak inab mihshi, Kulaija and Mamoul tamer) contribute less than $10 \%$ of food energy as a protein. Fat contribution in food energy is less than $20 \%$ for thirteen food items. On the other hand, six of selected traditional foods; namely: Harees, Moussakat bathenjan, Falafel, Hummus, Batata mihshi, and Kulaija, provide more than 35\% of food energy from fat. To avoid unhealthy weight gain and related non-communicable diseases, total fat should not exceed $30 \%$ of total energy intake [19]. Energy density is the energy amount per unit of food. Fortunately, foods with lower energy density provide less calories per gram of food. Therefore, people can have satisfying portions of these foods with a relatively low energy content, suggesting that diets with a low energy density is important to maintain a healthy body weight [20]. According to British Nutrition Foundation, very low energy density foods contain less than $0.6 \mathrm{kcal} / \mathrm{g}$, low energy density foods contain 0.6 to $1.5 \mathrm{kcal} / \mathrm{g}$, medium energy density foods contain 1.5 to 4 $\mathrm{kcal} / \mathrm{g}$, and high energy density foods contain more than 4 $\mathrm{kcal} / \mathrm{g}$ [21]. Thus, two food items (Mulukhiyah and Maraq bamieh) are considered as very low energy density foods, while only one food item (Kulaija) is considered as a high energy density food. Most of the analysed traditional foods are either low or moderate energy density foods (11 food items each).

Table 3. Energy Content and Contribution of Selected Traditional Foods Commonly Consumed in Saudi Arabia

\begin{tabular}{|c|c|c|c|c|c|c|}
\hline \multirow{2}{*}{ No. } & \multirow{2}{*}{ Food Items } & \multicolumn{2}{|c|}{ Energy Content } & \multicolumn{3}{|c|}{ Energy Contribution (\%) } \\
\hline & & Kcal/100g & $\mathbf{k J} / \mathbf{1 0 0 g}$ & Carbohydrate & Fat & Protein \\
\hline 1 & Gerish & 76 & 323 & 75 & 6 & 19 \\
\hline 2 & Qorsan & 83 & 351 & 68 & 13 & 19 \\
\hline 3 & Marqooq & 90 & 383 & 75 & 5 & 20 \\
\hline 4 & Marassia & 197 & 835 & 68 & 14 & 18 \\
\hline 5 & Harees & 94 & 394 & 48 & 39 & 13 \\
\hline 6 & Mulukhiyah & 17 & 73 & 60 & 13 & 27 \\
\hline 7 & Kabsah lahem & 137 & 580 & 71 & 12 & 16 \\
\hline 8 & Moussakat bathenjan & 215 & 892 & 15 & 69 & 17 \\
\hline 9 & Maraq bamieh & 28 & 118 & 62 & 8 & 30 \\
\hline 10 & Makaronah bebashamel & 134 & 563 & 49 & 34 & 17 \\
\hline 11 & Kushary & 158 & 665 & 69 & 26 & 6 \\
\hline 12 & Batata mihshi & 133 & 556 & 34 & 40 & 26 \\
\hline 13 & Henany & 325 & 1374 & 66 & 14 & 20 \\
\hline 14 & Mohala & 148 & 627 & 77 & 15 & 8 \\
\hline 15 & Aseedeh & 125 & 530 & 70 & 19 & 12 \\
\hline 16 & Fatayer sabanek & 209 & 886 & 77 & 12 & 10 \\
\hline 17 & Falafel & 279 & 1166 & 41 & 46 & 13 \\
\hline 18 & Foul mudames & 129 & 545 & 53 & 22 & 25 \\
\hline 19 & Hummus & 258 & 1073 & 25 & 62 & 13 \\
\hline 20 & Mafroud burr bread & 299 & 1271 & 91 & 3 & 5 \\
\hline 21 & Samouli burr bread & 294 & 1248 & 90 & 8 & 2 \\
\hline 22 & Warak inab mihshi & 122 & 514 & 63 & 28 & 9 \\
\hline 23 & Kulaija & 430 & 1805 & 57 & 37 & 6 \\
\hline 24 & Mutabak & 177 & 747 & 53 & 28 & 19 \\
\hline 25 & Mamoul tamer & 371 & 1565 & 70 & 25 & 5 \\
\hline
\end{tabular}


As shown in Table 4, the vitamin D content was measured in all selected traditional foods. Unfortunately, vitamin D was not detected in ten food items. However, the highest level of vitamin D was detected in Fatayer sabanek (75.88 IU/100g), followed by Mohala (33.93 IU/100g) and Gerish (20.52 IU/100g). On the other hand, low vitamin D levels were found in Mulukhiyah (1.80 IU/100g), Falafel (1.77 IU/100g) and Samouli burr bread (1.51 IU/100g). Uniquely, the current work is the first attempt, up to our knowledge, to study the vitamin D content of traditional foods commonly consumed in Saudi Arabia. Results indicate that Saudi traditional foods are poor sources of vitamin D. Low intake of vitamin D and high prevalence of vitamin D deficiency were documented in Saudi Arabia [2,22]. Most foods do not contain significant amounts of vitamin D. Therefore, food fortification with vitamin $\mathrm{D}$ is an important strategy to achieve vitamin D adequacy. Sadat-Ali et al. [23] evaluated the status of vitamin $\mathrm{D}$ fortification of commonly consumed food items by the Saudi population, including; fresh milk, yoghurt, powdered milk, cheese, cereals and orange juice. They found that most commonly consumed foods which are supposed to be vitamin D fortified were either not fortified or contain an amount less than recommended, by guidelines set for the US marketplace.
Thus, national strategies to improve and regulate food fortification with vitamin D is required in order to prevent the high prevalence of vitamin $\mathrm{D}$ deficiency.

Two major elements; calcium (13.62-91.37 mg/100g) and phosphorus (22.33-200.37 mg/100g), and one trace element; iron (0.51-4.44 mg/100g), were analyzed in this study (Table 4). Warak inab mihshi contains the highest amount of calcium $(91.37 \mathrm{mg} / 100 \mathrm{~g})$ followed by Falafel (83.59 mg/100g). Contrarily, Kabsah lahem and Aseedeh have the lowest amount of calcium (13.62 and 14.24 $\mathrm{mg} / 100 \mathrm{~g}$ respectively). The highest content of phosphorus was reported in Kulaija (200.37 mg/100g) followed by Hummus (194.77 mg/100g) and the lowest content of phosphorus was reported in Aseedeh (22.33 mg/100g). Again, Warak inab mihshi contains the highest amount of iron (4.44 mg/100g) compared with other traditional foods. Surprisingly, Kabsah lahem which contain cooked lamb meat with rice has the lowest amount of iron (0.51 mg/100g). Our results are consistent with those reported by Al-Kanhal et al. [9,10,11] for previously mentioned traditional Saudi foods regard having generally low content of calcium, phosphorus and iron. However, they reported a higher content of calcium, phosphorus (except for Foul mudames and Falafel) and iron (except for Harees, Foul mudames, Falafel and Hummus).

Table 4. Vitamin D, Minerals, Phytate and Oxalate Content of Selected Traditional Foods Commonly Consumed in Saudi Arabia.

\begin{tabular}{|c|c|c|c|c|c|c|c|}
\hline No. & Food Items & $\begin{array}{c}\text { Vitamin D } \\
\text { IU/100g }\end{array}$ & $\begin{array}{l}\text { Calcium } \\
\mathrm{mg} / 100 \mathrm{~g}\end{array}$ & $\begin{array}{c}\text { Phosphorus } \\
\text { mg/100g }\end{array}$ & $\begin{array}{c}\text { Iron } \\
\mathrm{mg} / 100 \mathrm{~g}\end{array}$ & $\begin{array}{l}\text { Phytate } \\
\text { mg/100g }\end{array}$ & $\begin{array}{c}\text { Oxalate } \\
\text { mg/100g }\end{array}$ \\
\hline 1 & Gerish & 20.52 & 58.07 & 82.09 & 0.58 & 30.91 & 1.22 \\
\hline 2 & Qorsan & ND* & 24.82 & 68.92 & 1.26 & 11.86 & 5.23 \\
\hline 3 & Marqooq & ND* & 29.07 & 79.34 & 1.47 & 45.28 & 5.55 \\
\hline 4 & Marassia & 19.34 & 66.26 & 142.75 & 1.94 & 68.66 & 1.17 \\
\hline 5 & Harees & 6.38 & 17.95 & 62.96 & 0.61 & 26.46 & 3.21 \\
\hline 6 & Mulukhiyah & 1.80 & 51.03 & 26.32 & 1.13 & 2.25 & 11.53 \\
\hline 7 & Kabsah lahem & 5.70 & 13.62 & 57.00 & 0.51 & 56.37 & 1.52 \\
\hline 8 & Moussakat bathenjan & $\mathrm{ND}^{*}$ & 22.80 & 75.45 & 0.98 & 10.69 & 12.08 \\
\hline 9 & Maraq bamieh & 7.83 & 74.59 & 42.42 & 0.52 & 15.11 & 1.03 \\
\hline 10 & Makaronah bebashamel & 4.18 & 30.63 & 67.11 & 0.71 & 20.85 & 3.36 \\
\hline 11 & Kushary & 7.28 & 17.74 & 56.86 & 1.15 & 30.44 & 3.34 \\
\hline 12 & Batata mihshi & 18.99 & 49.42 & 96.01 & 0.62 & 20.98 & 1.06 \\
\hline 13 & Henany & $\mathrm{ND}^{*}$ & 44.76 & 144.89 & 2.67 & 64.16 & 3.63 \\
\hline 14 & Mohala & 33.93 & 31.90 & 68.57 & 2.29 & 31.06 & 6.83 \\
\hline 15 & Aseedeh & $\mathrm{ND}^{*}$ & 14.24 & 22.33 & 1.82 & 8.76 & 2.33 \\
\hline 16 & Fatayer sabanek & 75.88 & 67.22 & 78.61 & 2.06 & 73.66 & 48.63 \\
\hline 17 & Falafel & 1.77 & 83.59 & 149.90 & 3.89 & 82.63 & 5.53 \\
\hline 18 & Foul mudames & $\mathrm{ND}^{*}$ & 21.16 & 120.87 & 1.43 & 53.26 & 1.02 \\
\hline 19 & Hummus & $\mathrm{ND}^{*}$ & 51.13 & 194.77 & 2.17 & 148.52 & 12.63 \\
\hline 20 & Mafroud burr bread & 3.53 & 29.65 & 184.97 & 3.75 & 86.18 & 9.30 \\
\hline 21 & Samouli burr bread & 1.51 & 31.71 & 143.99 & 3.38 & 91.38 & 2.66 \\
\hline 22 & Warak inab mihshi & $\mathrm{ND}^{*}$ & 91.37 & 35.10 & 4.44 & 27.06 & 3.77 \\
\hline 23 & Kulaija & $\mathrm{ND}^{*}$ & 34.34 & 200.37 & 3.22 & 108.50 & 11.19 \\
\hline 24 & Mutabak & 4.53 & 60.01 & 124.74 & 2.99 & 11.81 & 1.15 \\
\hline 25 & Mamoul tamer & ND* & 51.69 & 138.89 & 2.26 & 54.81 & 3.00 \\
\hline
\end{tabular}

$* \mathrm{ND}=$ Not Detected. 
Phytate and Oxalate contents were 2.25-148.52 mg/100g and 1.02-48.63 mg/100g respectively (Table 4). Phytate content exceeds $100 \mathrm{mg} / 100 \mathrm{~g}$ only in Hummus (148.52 $\mathrm{mg} / 100 \mathrm{~g})$ and Kulaija (108.50 mg/100g). Mulukhiyah has the least phytate content (2.25 mg/100g). Phytic acid (inositol hexose phosphate) present in most plant foods like cereals and legumes as phytate salt or a complex with protein. Phytic acid chelates with certain elements such as calcium and iron to form insoluble complexes, which adversely affect the bioavailability of these minerals [24]. Therefore, it is important to determine the phytate content of traditional foods, especially in relation to human nutrition and in the nutrient evaluation of foods. Almana [25] investigates the content of phytate in certain traditional Saudi foods, including; Burr bread, Gerish, Harees, Kabsah, Falafel, and Foul mudames. A higher content of phytate was reported by this report compared with the current data. Our results revealed that Fatayer sabanek has the highest oxalate content (48.63 $\mathrm{mg} / 100 \mathrm{~g}$ ) followed by Hummus (12.63 mg/100g). In contrast, Foul mudames, Maraq bamieh and Batata mihshi were reported with the lowest oxalate content (1.02 $\mathrm{mg} / 100 \mathrm{~g}, 1.03 \mathrm{mg} / 100 \mathrm{~g}$ and $1.06 \mathrm{mg} / 100 \mathrm{~g}$ respectively). To the best of our knowledge, this report is the first attempt to study the oxalate content of traditional foods commonly consumed in Saudi Arabia. Dietary oxalate found in plants and plant products, principally seeds and leafy plants. High intake of oxalate appears to play an important role in calcium oxalate kidney stone disease because of its absorption and excretion in urine [26]. In Saudi Arabia, the expected lifetime risk of a stone episode is $50 \%$ higher than in the Western countries, with predominantly (82\%) of calcium oxalate stones [27]. In addition, studies on stone formers in the Saudis have shown that the Saudi diet includes a higher intake of oxalate and lower intake of calcium than in the Western countries [27]. To prevent oxalate kidney stone disease, more steps appear to be required for decreasing the intake of oxalate-rich foods and increasing the intake of calciumrich foods [26].

Table 5. Nutrient Adequacy Ratio (\%) for 100g Serving of Selected Traditional Foods Commonly Consumed in Saudi Arabia for Middle Age Adults (31-50 year)

\begin{tabular}{|c|c|c|c|c|c|c|c|c|c|c|c|}
\hline \multirow[b]{2}{*}{ No. } & \multirow[b]{2}{*}{ Food Items } & \multicolumn{2}{|c|}{ Protein } & \multirow{2}{*}{$\begin{array}{c}\text { Carb. } \\
\text { M \& F } \\
130 \text { g/d }\end{array}$} & \multicolumn{2}{|c|}{ Fiber } & \multirow{2}{*}{$\begin{array}{c}\text { Vit. D } \\
\text { M \& F } \\
600 \text { IU/d }\end{array}$} & \multirow{2}{*}{$\begin{array}{c}\text { Calcium } \\
\text { M \& F } \\
1000 \mathrm{mg} / \mathrm{d}\end{array}$} & \multirow{2}{*}{$\begin{array}{c}\text { Phos. } \\
\text { M \& F } \\
700 \mathrm{mg} / \mathrm{d}\end{array}$} & \multicolumn{2}{|c|}{ Iron } \\
\hline & & $\begin{array}{c}M \\
56 \mathrm{~g} / \mathrm{d}\end{array}$ & $\begin{array}{c}F \\
46 \mathrm{~g} / \mathrm{d}\end{array}$ & & $\begin{array}{c}M \\
38 \mathrm{~g} / \mathrm{d}\end{array}$ & $\begin{array}{c}F \\
25 \mathrm{~g} / \mathrm{d}\end{array}$ & & & & $\begin{array}{c}M \\
8 \mathrm{mg} / \mathrm{d}\end{array}$ & $\begin{array}{c}F \\
18 \mathrm{mg} / \mathrm{d}\end{array}$ \\
\hline 1 & Gerish & 6.4 & 7.8 & 11.0 & 1.0 & 1.5 & 3.4 & 5.8 & 11.7 & 7.3 & 3.2 \\
\hline 2 & Qorsan & 7.1 & 8.7 & 10.9 & 2.2 & 3.3 & 0.0 & 2.5 & 9.8 & 15.8 & 7.0 \\
\hline 3 & Marqooq & 8.2 & 9.9 & 13.0 & 2.9 & 4.4 & 0.0 & 2.9 & 11.3 & 18.4 & 8.2 \\
\hline 4 & Marassia & 15.7 & 19.2 & 25.9 & 3.2 & 4.9 & 3.2 & 6.6 & 20.4 & 24.3 & 10.8 \\
\hline 5 & Harees & 5.3 & 6.5 & 8.7 & 1.7 & 2.6 & 1.1 & 1.8 & 9.0 & 7.6 & 3.4 \\
\hline 6 & Mulukhiyah & 2.1 & 2.5 & 2.0 & 1.4 & 2.1 & 0.3 & 5.1 & 3.8 & 14.1 & 6.3 \\
\hline 7 & Kabsah lahem & 9.9 & 12.0 & 18.8 & 1.2 & 1.8 & 1.0 & 1.4 & 8.1 & 6.4 & 2.8 \\
\hline 8 & Moussakat bathenjan & 15.8 & 19.3 & 6.1 & 5.9 & 9.0 & 0.0 & 2.3 & 10.8 & 12.3 & 5.4 \\
\hline 9 & Maraq bamieh & 3.8 & 4.6 & 3.3 & 1.3 & 2.0 & 1.3 & 7.5 & 6.1 & 6.5 & 2.9 \\
\hline 10 & Makaronah bebashamel & 10.2 & 12.4 & 12.6 & 1.4 & 2.2 & 0.7 & 3.1 & 9.6 & 8.9 & 3.9 \\
\hline 11 & Kushary & 3.9 & 4.7 & 20.9 & 1.3 & 2.0 & 1.2 & 1.8 & 8.1 & 14.4 & 6.4 \\
\hline 12 & Batata mihshi & 15.1 & 18.4 & 8.7 & 2.2 & 3.4 & 3.2 & 4.9 & 13.7 & 7.8 & 3.4 \\
\hline 13 & Henany & 28.9 & 35.2 & 41.5 & 5.3 & 8.0 & 0.0 & 4.5 & 20.7 & 33.4 & 14.8 \\
\hline 14 & Mohala & 5.3 & 6.4 & 21.9 & 2.8 & 4.3 & 5.7 & 3.2 & 9.8 & 28.6 & 12.7 \\
\hline 15 & Aseedeh & 6.4 & 7.8 & 16.8 & 0.8 & 1.2 & 0.0 & 1.4 & 3.2 & 22.8 & 10.1 \\
\hline 16 & Fatayer sabanek & 9.6 & 11.7 & 31.2 & 3.1 & 4.7 & 12.6 & 6.7 & 11.2 & 25.8 & 11.4 \\
\hline 17 & Falafel & 16.1 & 19.6 & 21.9 & 5.9 & 9.0 & 0.3 & 8.4 & 21.4 & 48.6 & 21.6 \\
\hline 18 & Foul mudames & 14.2 & 17.3 & 13.2 & 1.3 & 2.0 & 0.0 & 2.1 & 17.3 & 17.9 & 7.9 \\
\hline 19 & Hummus & 15.1 & 18.3 & 12.2 & 3.6 & 5.4 & 0.0 & 5.1 & 27.8 & 27.1 & 12.1 \\
\hline 20 & Mafroud burr bread & 7.3 & 8.9 & 52.5 & 2.5 & 3.8 & 0.6 & 3.0 & 26.4 & 46.9 & 20.8 \\
\hline 21 & Samouli burr bread & 2.4 & 2.9 & 50.9 & 2.6 & 4.0 & 0.3 & 3.2 & 20.6 & 42.3 & 18.8 \\
\hline 22 & Warak inab mihshi & 4.9 & 6.0 & 14.9 & 2.6 & 3.9 & 0.0 & 9.1 & 5.0 & 55.5 & 24.7 \\
\hline 23 & Kulaija & 12.2 & 14.8 & 47.2 & 2.7 & 4.0 & 0.0 & 3.4 & 28.6 & 40.3 & 17.9 \\
\hline 24 & Mutabak & 15.1 & 18.3 & 18.1 & 1.4 & 2.1 & 0.8 & 6.0 & 17.8 & 37.4 & 16.6 \\
\hline 25 & Mamoul tamer & 8.2 & 10.0 & 50.2 & 3.6 & 5.4 & 0.0 & 5.2 & 19.8 & 28.3 & 12.6 \\
\hline
\end{tabular}


The nutritional composition data become more meaningful when it is compared to the daily needs of the analyed nutrients. In the absence of local recommended intakes, the recommended intakes set by the Food and Nutrition Board of the Institute of Medicine, National Academies for the United States population [18], were used for comparison. The nutrient adequacy ratio (\%) for $100 \mathrm{~g}$ food serving size of selected traditional foods was calculated for middle-age adults (31-50 years) as shown in Table 5. Therefore, with a 100g serving size of different food items, the dietary requirement of different nutrients shall be met differently. This food serving supplies 2.1-28.9\% and 2.5-35.2\% of protein requirement for males (56 g/d) and for females (46 g/d) respectively. Similarly, carbohydrate requirement $(130 \mathrm{~g} / \mathrm{d})$ can be met between $2.0 \%$ and $52.5 \%$ for both genders with the same food serving size. However, men and women can obtain only $0.8-5.9 \%$ and $1.2-9 \%$ of their daily fibre needs respectively. While ten foods do not contribute with vitamin D needs (600 IU/d) as vitamin D was not detected in them, a similar $100 \mathrm{~g}$ serving size of the remaining foods contribute to $0.3-12.6 \%$ of daily requirement for both genders. In the same fashion, $1.4-9.1 \%$ of calcium needs $(1000 \mathrm{mg} / \mathrm{d})$ and $3.2-28.6 \%$ of phosphorus needs (700 $\mathrm{mg} / \mathrm{d})$ covered by the same serving size of these foods for both men and women. Middle-aged women have higher iron needs compared to their men counterparts (18 vs. $8 \mathrm{mg} / \mathrm{d}$ ). Therefore, a $100 \mathrm{~g}$ serving size of the studied foods can meet $6.4-55.5 \%$ and $2.8-24.7 \%$ of the daily iron requirement for men and women respectively.

Traditional Saudi foods generally have low to moderate fat content and based mainly on legumes and whole grains such as wheat and rice. Moreover, the glycemic index value of most traditional Saudi foods has fallen within the low range [28]. Therefore, starch presented in these foods is hydrolyzed slowly and thus absorbed at a slower rate in the small intestine. These important features of traditional Saudi foods suggest that these foods may have a role to play in the prevention and management of several chronic diseases, including obesity, cardiovascular disease, and diabetes mellitus where there is a high rate of prevalence of them in Saudi Arabia. The nutritive value and health aspects of traditional Saudi foods should be taken into consideration by Saudi dietary guidelines. Moreover, the consumption of healthy traditional foods in Saudi Arabia should be encouraged.

\section{Conclusions}

In conclusion, the nutritional composition of traditional foods commonly consumed in Saudi Arabia indicates that most of these foods are good sources of carbohydrate, moderate sources of protein, fat, phosphorus, and iron and low sources of dietary fibre, vitamin $\mathrm{D}$, and calcium. Moreover, they provide substantial amounts of phytate and smaller amounts of oxalate. Traditional Saudi foods can be used in the prevention and management of obesity, cardiovascular disease and diabetes mellitus. Saudi dietary guidelines should take into consideration the nutritive value and health aspects of these foods and encourage the consumption of healthy traditional foods. The findings of this study will be useful in clarifying nutrient and energy contribution from common traditional foods in Saudi Arabia and have potentially useful applications in planning normal and therapeutic diets. Further research on the nutritional value of other commonly consumed traditional foods in Saudi Arabia is needed.

\section{Acknowledgments}

The author thanks the Scientific Council Secretariat at Princess Nourah Bint Abdulrahman University, Riyadh, Saudi Arabia for logistical support.

\section{Statement of Competing Interests}

The author has no competing interests.

\section{References}

[1] Abla, M.S., Nasreddine, L., Mokdad, A.H., Adra, N., Tabet, M. and Hwalla, N., "Nutrition transition and cardiovascular disease risk factors in the Middle East and North Africa countries: reviewing the evidence," Annals of Nutrition and Metabolism, 57 (3-4). 193-203. 2010.

[2] ALFaris, N.A., Al-Tamimi, J.Z., Al-Jobair, M.O., and Al-Shwaiyat, N.M., "Trends of fast food consumption among adolescent and young adult Saudi girls living in Riyadh,” Food \& Nutrition Research, 59. 26488. 2015.

[3] Mabry, R., Koohsari, M.J., Bull, F., and Owen, N., "A systematic review of physical activity and sedentary behaviour research in the oil-producing countries of the Arabian Peninsula,” BMC Public Health, 16 (1). 1003. 2016.

[4] Memish, Z.A., "Obesity and associated factors-Kingdom of Saudi Arabia, 2013,” Preventing Chronic Disease, 11. 140236. 2014.

[5] International Diabetes Federation, "Middle East and North Africa: Saudi Arabia,” [Online]. Available: http://www.idf.org/membership/mena/saudi-arabia.[Accessed January 24, 2017].

[6] Kumosani, T.A., Alama, M.N., and Iyer, A., "Cardiovascular diseases in Saudi Arabia," Prime Research on Medicine, 1. 1-6. 2011.

[7] Trichopoulou, A., Soukara, S., and Vasilopoulou, E., "Traditional foods: a science and society perspective," Trends in Food Science \& Technology, 18 (8). 420-427. 2007.

[8] Khokhar, S., Gilbert, P.A., Moyle, C.W.A., Carnovale, E., Shahar, D.R., Ngo, J., Saxholt, E., Ireland, J., Jansen-van der Vliet, M. and Bellemans, M., "Harmonised procedures for producing new data on the nutritional composition of ethnic foods," Food Chemistry, 113 (3). 816-824. 2009.

[9] Al-Kanhal, M.A., Al-Mohizea, I.S., Al-Othaimeen, A.I., and Khan, M.A., "Nutritive value of some wheat based dishes consumed in the Kingdom of Saudi Arabia," Ecology of Food and Nutrition, 32 (3-4). 219-226. 1994.

[10] Al-Kanhal, M.A., Al-Mohizea, I.S., Al-Othaimeen, A.I., and Khan, M.A., "Nutritional evaluation of some legume-based dishes consumed in Saudi Arabia," International Journal of Food Sciences and Nutrition, 49 (3). 193-197. 1998.

[11] Al-Kanhal, M.A., Al-Mohizea, I.S., Al-Othaimeen, A.I., and Khan, M.A., "Nutritive value of various rice-based dishes in Saudi Arabia," Ecology of Food and Nutrition, 38 (3). 223-235. 1999.

[12] ElObeid, T., Phoboo, S. and Magdad, Z., "Proximate and Mineral Composition of Indigenous Qatari Dishes: Comparative Study with Similar Middle Eastern Dishes,” Journal of Food Chemistry and Nutrition, 3 (1). 27-34. 2015.

[13] Musaiger, A.O., Al-Jedah, J.H., D'Souza, R., "Nutritional profile of ready-to-eat foods consumed in Bahrain," Ecology of Food and Nutrition, 46 (1). 47-60. 2007.

[14] Habib, H.M., Ali, H.I., Ibrahim, W.H., and Afifi, H.S., "Nutritional value of 10 traditional dishes of the United Arab Emirates," Ecology of Food and Nutrition, 50 (6). 526-538. 2011. 
[15] Association of Official Analytical Chemists, Official Method of Analysis, AOAC, Washington (DC), 19th edition, 2012.

[16] Haq, A., "Vitamin D: A Molecule of Universal Interest and Its Measurement," Journal of Chromatography \& Separation Techniques, 4. e117. 2013.

[17] Mameesh, M.S., and Tomar. M., "Phytate content of some popular Kuwaiti foods,” Cereal Chemistry, 70. 502-503. 1993.

[18] Food and Nutrition Board, Institute of Medicine, Dietary Reference Intakes: The Essential Guide to Nutrient Requirements, National Academies Press, Washington (DC), 2006.

[19] Food and Agriculture Organization of the United Nations, Fats and Fatty Acids in Human Nutrition: Report of an Expert Consultation, FAO, Geneva, 2010.

[20] Bechthold, A., "Food energy density and body weight," Ernahrungs Umschau, 6. 2-11. 2014.

[21] British Nutrition Foundation, "What is energy density?," [Online]. Available: https://www.nutrition.org.uk/healthyliving/fuller/whatis-energy-density.html. [Accessed January 24, 2017].

[22] Al-Faris, N.A., "High Prevalence of Vitamin D Deficiency among Pregnant Saudi Women,” Nutrients, 8 (2). 77. 2016
[23] Sadat-Ali, M., Al Elq, A., Al-Farhan, M., and Sadat, N.A., "Fortification with vitamin D: Comparative study in the Saudi Arabian and US markets," Journal of Family and Community Medicine, 20 (1). 49-52. 2013.

[24] Kumar, V., Sinha, A.K., Makkar, H.P., and Becker, K., "Dietary roles of phytate and phytase in human nutrition: A review," Food Chemistry, 120 (4). 945-959. 2010.

[25] Almana, H.A., "Extent of phytate degradation in bread and various foods consumed in Saudi Arabia." Food Chemistry, 70 (4). 451456. 2000.

[26] Holmes, R.P., and Assimos. D.G., "The impact of dietary oxalate on kidney stone formation,” Urological Research, 32 (5). 311-316. 2004.

[27] El-Faqih, S.R., Epidemiology of Stone Disease in Saudi Arabia with an Overview of the Regional Differences, In: Talati, J.J., Tiselius, H.G., Albala, D.M., YE, and Z., Urolithiasis: Basic Science and Clinical Practice, Springer, London, 2012, 77-83.

[28] Al-Mssallem, M.Q., "The Association between the Glycaemic Index of Some Traditional Saudi Foods and the Prevalence of Diabetes in Saudi Arabia: A Review Article," Journal of Diabetes \& Metabolism, 5. 11. 2014. 